\title{
Some aspects of health status of the Gypsy population in Slovakia
}

\author{
Bartosovic I \\ St. Elisabeth University of Health and Social Sciences, Bratislava, Slovakia. ivan.bartosovic@gmail.com
}

\begin{abstract}
Population of the Gypsy people living currently in Slovakia reaches approximately 400000 people which represents $7.5 \%$ of the total Slovak population. The age structure of the Gypsy population is of a considerably progressive type with a high number of children and very low number of old people. This is due to the high natality and high mortality of Gypsies, whose health status is worse than the health status of the majority population. Gypsy people represent an important „old-new“ risk group in case of tuberculosis and a more frequent occurrence of other transmitted diseases is observed in them while a higher incidence of genetically conditioned diseases has been confirmed, as well. As for children, a higher frequency of infectious diseases, injuries, intoxications and burns can be found as a result of their environmental conditions. A high level of infant mortality of the Gypsy children is a very negative phenomenon.

We can state that the lifestyle of the Gypsy population is unhealthy, characterized by bad dietary habits, drinking alcohol, frequent smoking already in a very young age, higher weight and lower physical activity. All findings confirm that the Gypsy population is threatened by cardiovascular diseases at younger age already. Due to a more difficult approach to the health care, part of the Gypsies consult the physician only when in a serious health state. Health status of the Gypsy seniors has been reported only at minimum due to their low representation in population. Typical feature of this ethnic is, that they take care of their seniors. To prove this, during the author's twenty seven-year practice he met just three old Gypsy women in social institutions.

It is very difficult to address problems related to the Gypsy population; this task requires engagement of all spheres of our society, in particular of the Gypsies themselves, including their organizations (Ref. 50). Text in PDF www.elis.sk.

KEY WORDS: Gypsy population, life expectancy, infectious diseases, genetic disorders, cardiovascular risk factors, lifestyle, nutrition, health status, Gypsy children, Gypsy seniors.
\end{abstract}

\section{Introduction and demography}

In Slovakia there are currently about 403000 Gypsy representing $7.5 \%$ of the total number of population (1). Official number (i.e. more than 105000 in line with the 2010 census) does not correspond to the real number since a great part of Gypsies does not claim their Gypsy nationality (2).

The Gypsy population has a considerably progressive type of age structure with a great quota of children and a very low quota of old people. This is due to the Gypsy high natality and high mortality being for a long time considerably higher than with non-Gypsy population (3). Thus, children under 14 years represent approximately $39.4 \%$ of the Gypsy population while seniors being more than 60 years old represent $2.1 \%$ of the total Gypsy population (4). Life expectancy is shorter than in the non-Gypsy population. In case of inhabitants of the Gypsy communities (the Gypsy people represent three quarters and more out of the total population) in 1992-2012, life expectancy at birth was by 6.2 years shorter in the

St. Elisabeth University of Health and Social Sciences, Bratislava, Slovakia.

Address for correspondence: I. Bartosovic, MD, PhD, Dolezalova 12, SK-909 01 Skalica, Slovakia.

Phone: +421.346645332
Gypsy men than in the non-Gypsy men in Slovakia. Taking into account the Gypsy women, their life expectancy at birth was by 8.8 years lower compared to the non-Gypsy Slovak women (4). Fertility rate and birth rate are higher with the Gypsy women. Their average age at the first delivery achieves lower values against other population while the Gypsy women have an increased number of illegitimate children (5). Mortality of the Gypsy is higher than in case of the majority population. This is obviously due to a lower life expectancy and higher infant mortality. Infant mortality (i.e. $16.6 \%$ in the Gypsy people) is 1.8 times higher in the Gypsy population than in Slovakia, while in non-integrated Gypsies (20 $\%$ ) it is 2.2 times higher than in Slovakia (6). Pursuant to the study worked out by Krak and co., an average age of Gypsy people at death was much lower compared to the majority group, in some cases even by 20 years to the detriment of the Gypsy men. In one of the districts under observation, only $49 \%$ of the Gypsies managed to attain their senior age (more than 60 years) against $78 \%$ of the majority population (7).

\section{Health status}

In general, the health status of the Gypsy population is considered to be worse than the health status of the majority population. Under the Report on the health status of inhabitants in Slovak Re- 
public the Gypsy health state is characterized as very bad. Gypsy represent a high risk group of population in Slovakia endangered with obesity, diabetes mellitus, cardiovascular system problems and some kinds of tumors e.g. lung cancer (8). Health state is influenced also by integration of the Gypsy population in which we recognize three groups: integrated Gypsy people (in our country about $30 \%$ ); partially integrated Gypsy people (their number is about $40 \%$ of the Gypsy population); non-integrated Gypsy people (representing about $30 \%$ of the Gypsy population (9). Majority of health problems and specifics is closely linked with non-integrated or partially integrated Gypsy population (9).

\section{Infectious diseases}

The Gypsies are an important „old-new“ risk group of tuberculosis (10). In 2013, about 401 new cases of tuberculosis were recorded, out of which 108 (i.e. $26.4 \%$ of the total amount) cases emerged with the Gypsy ethnic group. Its existence with children younger than 14 years is alarming - in 2010 the children tuberculosis found with Gypsies achieved a high amount of $90.9 \%$ (11). The source of infection with children remains very often unidentified however it is the child's father or its grand-parents who prevail as a known source of infection. It is relatively difficult to diagnose child's tuberculosis since this disease in children is rarely linked with bacteriological positivity. Further treatment of a child after leaving the hospital is not adequate, either the treatment is often arbitrarily interrupted or the medicine is not taken regularly, these children don't come for medical examination (12). In comparison to the majority population the Gypsy ethnic group has its specific features being applied in spreading infection and having impact on epidemiologic development of situation. These specifics include bad socio-economic conditions, discrepancies in regional occurrence, shorter institutional treatment, non-comprehension of the following treatment in dispensaries, more-generation cohabitation in communities lacking basic sanitary standards, impossibility of complex examination of contacts (13).

Furthermore, a more frequent prevalence of other transmitted diseases (e.g. shigellosis, invasive meningococcal infections, scabies) has been observed among the Gypsy people (14). Morbidity related to hepatitis A demonstrates a permanently decreasing tendency, while the Gypsy morbidity achieving 50-60\% of the total number of sick people per year highly exceeds morbidity of the remaining Slovak population. Prevalence of this disease prevails in locations with a low hygienic standard, mainly in the Gypsy communities and in areas with high concentration of the Gypsy ethnics (15). Morbidity relating to the hepatitis A virus is 2.86 higher with Gypsies than with other population while more than $80 \%$ of cases have epidemic development (16). In crosssectional HepaMeta study the authors found out that the prevalence of active hepatitis B in the Gypsy population in segregated communities was $12.5 \%$, which is much higher than the average prevalence in the Slovak Republic (1.7\%) and 52.9\% had come into contact with hepatitis B virus in the past or present. Hepatitis C prevalence was very low $(0.7 \%)$, which is probably due to very low intravenous drug use (17).

\section{Genetic disorders}

A higher prevalence of genetically determined diseases has been confirmed among the Gypsy population. One of its causes is the fact that the Slovak Gypsies represent a population with the highest coefficient of inbreeding in Europe which is increasing the probability of recessive genetic diseases. In case of 444 Vlachika Gypsies from 101 families the authors found out that their coefficient of inbreeding of 0.017 and 0.084 represents the highest value within European population similarly to India. The number of consanguine marriages amounted to $30.7 \%$ (most usually between two cousins - boy-cousin and girl cousin (18). Authors of another study proved higher prevalence and incidence of primary congenital glaucoma in the Gypsy population (19). The Gypsy ethnic group represents a risk group for the occurrence of deficiency in acyl-CoA dehydrogenase of fatty acids with medium chain (MCAD) (20). Mutations of GJB2 gene (connexin 26) are the main reason of autosomal recessive non-syndromic hearing loss while mutation of W24X gene was found in India, Pakistan and with Slovak Gypsies (21). The Gypsies in East Slovakia suffer from autosomal recessive form of retinitis pigmentosa characteristic of its serious clinical picture even in pre-school age, patients loose gradually their sight due to progressive degeneration of their photoreceptors (22). Congenital hypothyroidism belongs to typical inborn diseases of the Gypsy population (incidence with the Gypsies $1: 2192$, with other population $1: 6284$ ). Increased incidence of congenital hypothyroidism in Gypsy newborns was identified even 3.5 years after introducing compulsory screening program of newborns for this disease in Slovakia (23).

\section{Gypsy children population}

With Gypsy children there is a higher prevalence of infectious diseases, injuries, intoxications and burns resulting from their environmental conditions. In districts of the former East Slovak region we have recorded an increased number of Gypsy children treated and hospitalized due to respiratory infections and digestion problems (24). While monitoring breast-feeding in Slovakia with the children born in 1997, the authors came to conclusion that the Gypsy mothers feed their children by breast for a long time and in a high percentage. There are distinctions in some significantly backward enclaves in the north where breast-feeding is still taken for traditional nutrition against the Gypsies in southern Slovakia who prefer artificial nutrition (25). The risk factors of Sudden Infant Death Syndrome (SIDS) include socio-economic state of the family, sanitation standard of housing, smoking of mothers, education closely interlinked with care for children. The Gypsy children represented as many as $24 \%$ of all cases in a group with SIDS while $73.9 \%$ of the Gypsy mothers smoked and $83.3 \%$ lived in poor sanitation conditions. A more frequent incidence of this serious sudden death with the Gypsy ethnics has been confirmed (26). With respect to information on mental retardation, it can be drawn from the only work of Slovak authors who monitored genetically conditioned mental retardation with 6-14 years old children in the district of Banska Bystrica in 1987. Mental retardation was 
discovered in $21.5 \%$ of Gypsy children out of the total number of 23510 children while only $0.9 \%$ of non-Gypsy children were affected. Despite the fact that only $6 \%$ of the monitored group members were the Gypsy children their share on mental retardation amounted to $60.7 \%$ (27). However, it is necessary to emphasize that so far there is no sufficiently valid test to identify mental retardation within the Gypsy minority (6).

Anthropometric cross-sectional survey in 3-12 years old children has confirmed remarkable retardation of the Gypsy children related to their height, weight and other anthropometric indicators compared with national results. Body Mass Index (BMI) of the Gypsy and the non-Gypsy children is not evidently different, but the research points at accumulation of fat to visceral area which is a risk factor for central obesity and metabolic syndrome. Comparing the Gypsy children to non-Gypsy ones, the former are smaller and lighter as a result of their worse socio-economic factors, genetic factors, nutritional deficiency and the fact that the Gypsy population still forms quite isolated social group $(28,29,30)$.

High infant mortality of the Gypsy children is a very unfavorable phenomenon (31). This is essentially due probably to their low natality weight resulting from an increased incidence of premature births, more frequent use of addiction drugs, unsuitable life conditions of pregnant women (6). Risks in connection with the Gypsy mothers and their newborns include several factors such as missing education towards maternity, frequent successive pregnancies one by another, minimal prenatal care, lack of confidence in health system, escapes from hospital, late arrival to hospital to give birth, more frequent deliveries at home without professional assistance, insufficient hygiene, nutrition, life regimen and low level of health awareness, infections during pregnancy (32). As a result, the number of the Gypsy premature newborns is three times higher against the majority, 4-5 times higher number of the Gypsy hypotrophic newborns compared to the majority newborn population, 2-3 times more frequent serious diseases (infections, hypoxia etc.) endangered Gypsy newborns life and development, overwork with respect to intensive newborn care facilities in the regions with a high number of the Gypsy newborn babies (32). Low vaccination of the Gypsy children can be understood as a result of some Gypsy parent's irresponsible approach to vaccination, migration of the Gypsy children, problems linked with vaccination of children with low birth weight (33).

\section{Lifestyle and risk factors}

Lifestyle of the Gypsy ethnicity is unhealthy, characterized by bad dietary practices, drinking alcohol, frequent smoking already in a very young age, higher weight and lower physical activity (34). The way of preparing food is influenced by their culture, but also by their economic situation, level of knowledge of healthy food and their way of living. The present situation in eating reflects the social and economic situation of the Gypsy people (35). Traditional families prefer high-calories food with high consumption of fat meat, excessive consumption of animal or plant fats due to their price affordability and high caloric value. Low consumption of milk and diary products is typical as a result of more frequent lactose intolerance, traditional designation of milk as inappropriate foodstuff and its relatively high price (35).

Slovakia is a leading country in assessing the cardiovascular risk factors with Gypsy people (36). When comparing Gypsies to other majority population, the former had a higher level of triglycerides, an elevated atherogenic index, lower levels of HDL cholesterol, higher levels of insulin and insulin resistance, lower values of vitamin C. Gypsies consume more animal fat, pork, charcuterie, eggs, alcoholic beverages, they smoke more and they are in worse physical condition $(37,38)$. Another study comparing nutrition of the Slovaks, Hungarians and Gypsies from southern Slovakia showed that high consumption of fat meat, charcuterie, pork lard due to their low price were typical for the Gypsy people together with sweet lemonades, low consumption of whole-grain products, vegetables and fruit (39). According to another study, overweight and obesity were more frequent with the Gypsies in western Slovakia (34.2\%) against the majority population (15.1 $\%)$. Prevalence of diabetes is assessed to reach 15-20\% with the adult Gypsy population against the total Slovak population where diabetes amounts to more than $5 \%$ (40). In 2011, the authors of the abovementioned study HepaMeta compared a group of 452 inhabitants of the Gypsy communities and 403 inhabitants of the majority being $18-55$ years old from the Kosice region. In the case of Gypsies they have found higher consumption of sweet drinks and farinaceous meals, lower consumption of milk products, fruit and vegetables (34). In other works the Gypsies had lower levels of vitamins antioxidants (vitamin $\mathrm{C}$, beta-carotene) correlating with inappropriate nutrition ( fruit and vegetables low consumption), insufficient knowledge of optimal nutrition due to low degree of education and smoking (41). All these findings prove that the Gypsy population is threatened by cardiovascular diseases in younger age already (42).

Obstructive sleep apnoea (OSA) is considered a risk factor for cardiovascular disorders in particular in the presence of obesity, higher age, smoking and alcohol consumption. The Kosice authors monitored seriousness of the obstructive sleep apnoea in 137 non-Gypsy patients and 23 Gypsy patients sent for polysomnographic examination. More II type diabetes was found in the Gypsy people than in non-Gypsy population along with a higher waist circumference and higher plasmatic levels of glycaemia during fasting. An OSA diagnosis was confirmed in $91 \%$ of the Gypsy population and $65 \%$ of non-Gypsy persons while Gypsies had a higher probability of serious degree of OSA (74 \% Gypsies against $28 \%$ non-Gypsy population) (43).

\section{Addictions}

There is few information on taking drugs in the Gypsy communities. Members of some Gypsy communities are supposed to take drugs based on organic solvents (toluene sniffing); this is connected mainly with men of the socially weakest group evaluated very negatively by the Gypsy themselves. For the time being, the hard drugs can only be found rarely in the Gypsy communities, however in the cities their raising tendency has been confirmed. The so-called legal drugs (cigarettes and alcohol) prevail 
to a significant extent but their consumption differs a lot depending on community (44). Almost in all of the Gypsy communities an excessive consumption of medications (especially Ibuprofen, Paracetamol and Diazepam) was reported; this is linked with the Gypsy people higher morbidity (44). The data according to which $7.8 \%$ of the children aged $0-9$ years take tranquilizers, relaxants and medicinal products for sleeping is really alarming; this is to a great measure an unsuitable way of calming the children when parents need to have a rest from them (9).

Smoking is very frequent with the Gypsy ethnics, in a relatively low age already, in line with most of the mentioned studies about $50-60 \%$ of the Gypsy people smoke $(37,38,45,46)$. Despite a generally stated increased consumption of alcoholic beverages in the Gypsy ethnics, HepaMeta study did not find differences in drinking alcohol between the Gypsy and the non-Gypsy men. However, Gypsy women reported less frequent drinking and binge drinking of 6 or more doses of alcohol on a single occasion $(47,48)$.

\section{Access to health care}

As a result of more difficult access to health care due to different factors (great distance from policlinics, insufficient hygiene, discrimination in health establishments, financial unavailability of prescribed drugs, communication problems among healthcare professionals and Gypsy patients etc.), part of the Gypsy population do not consult the doctor until they are in a very serious health state (9). Belak is pointing also at the limits of the health systems which could paradoxically contribute to the bad health state of the Gypsy population. It can be said that Gypsy-specific limitations in emergency-rescue and clinical practices include poor functionality of clinical standards, aggressive Gypsy behavior, counselling and welfare workload beyond scope of profession, low hygienic standards within segregated Gypsy settlements and truly racist practice (49).

\section{Gypsy seniors}

Health status of the Gypsy seniors has been reported only at minimum due to their low representation in population. Old people enjoy great respect in a traditional community and in a family, from an authority point of view we can even speak of a ,seniorate" (50). Respect showed for seniors leads to the fact that the Gypsies take care themselves for elderly people and, consequently, care provided by institutions is seldom used. Based on my own experience I can state that during my 27-year medical practice in retirement home and establishment for seniors I met only three old Gypsy women there.

\section{Conclusions}

Care for the Gypsy population health is not just the problem of Slovakia, it is a problem in the whole Europe and it must be addressed in a complex way with active cooperation of the state and the Gypsy population. Addressing the Gypsy problems is a very difficult affair that needs the involvement of all spheres of our society, in particular the Gypsies themselves and their organizations. To achieve this goal it will be necessary to respect the specifics of the Gypsy ethnics, their different historical origin, their mentality and culture. Results can be expected no sooner than in future generations $(28,29)$.

\section{References}

1. United Nations Development Programme. Atlas rómskych komunít na Slovensku 2013. Bratislava: UNDP, 2014: 122.

2. Matlovičová K, Matlovič R, Mušinka A, Židová A. The Gypsy population in Slovakia. Basic characteristics of the Gypsy population with emphasis on the spacial aspects of its differentiation. In: Penczes J, Radics Z (Eds). Gypsy population on the peripheries of the Visegrad countries. Spatial trends and social challenges. Debrecen: 2012, 77-104.

3. Vaňo B. Demografická charakteristika rómskej populácie v SR. Bratislava: Infostat, 2001. Dostupné na: http://www.infostat.sk/vdc/pdf/rom.pdf.

4. Šprocha B. Reprodukcia rómskeho obyvatel'stva na Slovensku a prognóza jeho populačného vývoja. Bratislava: Prognostický ústav SAV, 2014. Dostupné na: http://www.infostat.sk/vdc/pdf/Romovia.pdf.

5. Vaňo B, Mészáros J. Reprodukčné správanie obyvatel’stva v obciach s nízkym životným štandardom. Bratislava: Infostat, 2004. Dostupné na: http://www.infostat.sk/vdc/pdf/nizkyzs.pdf.

6. Šprocha B. Úmrtnost' rómskej populácie na Slovensku. Demografie 2008; 50 (4): 276-287.

7. Krak J, Mittlöhnerová V, Václavová M. Úmrtnost' rómskej populácie v spádovom regióne RUVZ so sídlom v Poprade a možnosti jej ovplyvnenia. Verejné zdravotníctvo 2007; 1. Dostupné na: http://www.szu.sk/ine/ verejnezdravotnictvo/2007/2007-1/krak. htm

8. Ministerstvo zdravotníctva SR. Správa o stave zdravotnom stave obyvatel'ov SR. Bratislava: Ministerstvo zdravotníctva, 2006. Dostupné na: http://www.health.gov.sk/redsys/rsi.nsf/0/82375094098a41dbc12571 e3003d4519/\$FILE/vlastnymat.pdf.

9. Popper M, Szeghy P, Šarkozy Š. Rómska populácia a zdravie: Analýza zdravotnej situácie na Slovensku. Bratislava PDCS; 2009: 97.

10. Solovič I, LittvaV. Tuberkulóza - staronová hrozba pre svet. Inter Med 2007; 7(2): 70-73.

11. Švecová J, Solovič I. Tuberkulóza u príslušníkov rómskeho etnika. In: Ferencová E, Švecová J, Kober L (Eds). Ošetrovatel'ská starostlivost' v pneumológii, ftizeológii a hrudníkovej chirurgii. Vyšné Hágy; 2011: 97-101.

12. Švecová J, Solovič I. Starostlivost' o rizikových pacientov s tuberkulózou. Sestra a lekár v praxi 2007; 6 (5-6): 24-27.

13. Solovič I, Juriš P, Lauková P, Petrová G, Kováč A, Švecová J. Tuberkulóza a parazitózy u marginalizovanej rómskej populácie na Slovensku. Verejné zdravotníctvo 2011; 8 (2). Dostupné na: http://www.verejnezdravotnictvo.szu.sk/SK/2011/2/Solovic.pdf.

14. Bertková I, Petrášová D. Chorobnost' ako jeden z ukazovatel'ov zdravotného stavu rómskej populácie. Slov Lek 2004; 14 (28) (11-12): 332-334.

15. Sláčiková M. Aktuálna problematika VHA a VHB. Via practica 2006; 3 (7/8), 351-355.

16. Bérešová M, Taragel'ová B. Dynamika zmien v incidencii vírusovej hepatitídy typu A v okrese Rimavská Sobota v rokoch 1977-2006. Lek Obzor 2008; 56 (12): 512-513. 
17. Veselíny E, Janíčko M, Dražilová S et al. High hepatitis B and low hepatitis C prevalence in Gypsy population in Eastern Slovakia. Centr Eur J Public Health, Supplement 2014; 22: S51-S56.

18. Ferák V, Siváková D, Sieglová Z. Slovenskí cigáni (Rómovia) - populácia s najvyšším koeficientom inbrídingu v Európe. Bratisl Lek Listy 1987; 87 (2): 168-175.

19. Genčík A. Epidemiology and genetics of primary congenital glaucoma in Slovakia. Description of a form of primary congenital glaucoma in gypsies with autosomal-recessive inheritance and complete penetrance. Dev Ophtalmol 1989; 16: 76-115.

20. Bzdúch V. Vyšší výskyt poruchy MCAD v rómskej populácii. Med Monitor 2001; 7 (6): 6-7.

21. Minarik G. Mutácie génu GJB2 u rómskych pacientov s nesyndrómovou hluchotou (NSHL). Čas Lék Čes 2003; 142 (5): 315-316.

22. Ficek A, Ferák V, Feráková E, Kádasi L', Minárik G, Poláková H. Identifikácia a charakterizácia génu zodpovedného za vznik retinálnej degenerácie častej u slovenských Rómov. Čas Lék Čes 2003; 142 (5): 316.

23. Lescisinová M, Kúseková M, Sedlák J, Murková V, Langer P, Pavkovceková O. Increased incidence of congenital hypothyroidism in Gypsies in east Slovakia as compared with white population. Endocrinol Exp 1989; 23 (2): 137-141.

24. Mocová E. Je potrebné zaoberat' sa otázkou Rómov v pediatrickej praxi? Čs Pediat 1990; 45 (5): 290-292.

25. Dluholucký S. a praktickí lekári pre deti a dorast. Etnické a geografické rozdiely v dojčení na Slovensku. Lek Obzor 1999; 48 (7-8): 209-212.

26. Jura J. Syndróm náhleho úmrtia u dojčiat. Pediatrie Prax 2002; 3 (5): $218-224$

27. Kvasnicová M, Puskailerová D, Csomóová $\mathbf{E}$ et al. Geneticky podmienená mentálna retardácia v okrese Banská Bystrica. Čs Pediat 1992; 47 (1): $25-28$.

28. Rimárová K, Bernasovská K, Tutokyová A, Holéczyová G. Základné antropometrické a socio-ekonomické charakteristiky rómskej populácie. Slov Lek 2006; 16 (30) (1-2): 46-49.

29. Rimárová, K. The Health of the Gypsy people in Central and Eastern Europe. Košice: Univerzita Pavla Jozefa Šafárika, 2010: 1-100.

30. Koval' J, Mrosková S, Magurová D. Nutrition of the Gypsy children and its impact on some indicators of health. Medycyna Srodowiskowa/ Environmental Medicine 2012; 15 (1): 69-74.

31. Koval' J, Kuchta M. Analýza príčin a dynamika úmrtnosti u detí vo východoslovenskom regióne. Lek Obzor 2013; 62 (7-8): 268-273.

32. Frič I. Ku problematike rómskej minority v starostlivosti o matku novorodenca. Neonatologické zvesti 2003; 7 (1): 31-32.

33. Úrad verejného zdravotníctva SR. Vyhodnotenie administratívnej kontroly očkovania v Slovenskej republike k 31.8.2013. Dostupné na: http://www.uvzsr.sk/docs/info/epida/Vyhodnotenie_administrativnej_kontroly_ockovaniav_SR_k_31082013_komentar.pdf.

34. Hijová E, Madarasová-Gecková A, Babinská I, HepaMeta tím. Stravovacie zvyklosti a výživa Rómov. Lek Obz 2012; 21 (10): 358-362.
35. Kačala O, Ginter E, Kovacic V, Kudláčková M, Valachovičová M. Zložitost' problematiky rómskej menšiny na Slovensku a jej zdravotný stav. Med Monitor 2001; 7 (4): 24-26.

36. Dobranici M, Buzea A, Popescu R. The cardiovascular risk factors of the Gypsy (Gypsies) people in Central-Eastern Europe: a review of the published literature. J Med Life 2012; 5 (4): 382-389.

37. Krajcovicova-Kudlackova M, Blazicek P, Spoustova V, Valachovicova M, Ginter E. Cardiovascular risk factors in young Gypsy population, Bratisl Lek Listy 2004; 105 (7-8): 256-259.

38. Krajčovičová-Kudláčková M, Ginter E, Blažíček P. et al. Riziko aterosklerózy v skupine etnickej minority Rómov južného Slovenska. Cor Vasa 2002; 44 (9): 370-374.

39. Kačala O, Ginter E, Kovačic V, Kudláčková M, Valachovičová M. Porovnanie výživy Slovákov, Mad’arov i Rómov na národnostne zmiešanom území Slovenska. Med Monitor 2002; 8 (1): 22-24.

40. Ginter E. Prevalencia obezity a diabetu na Slovensku a v USA. Med Monitor 2002; 8 (3): 37-38.

41. Valachovicova M, Krajcovicova-Kudlackova M, Ginter E, Paukova V. Antioxidant vitamin levels - nutrition and smoking. Bratisl Lek Listy 2003; 104 (12): 411-414.

42. Ginter E, Havelkova B, Rovny I, Hlava P, Barakova A, Kudlackova M. Health status of the Slovakia population at its entry to the European Union. Bratisl Lek Listy 2005; 106 (2): 45-54.

43. Sopková Z, Dorková Z, Joppa P, Tkáčová R. Závažnost' obštrukčného spánkového apnoe u rómskych a nerómskych pacientov. Inter Med 2012; 12 (6): 249-253.

44. Mušinka A. Užívanie drog v rómskych komunitách Prešovského kraja. Človek a spoločnost' 2007; 3. Dostupné na: http://www.saske.sk/cas/3-2007/05-musinka.html.

45. Krajčovičová-Kudláčková M, Blažíček $P$, Ginter E, Spustová V. Non-lipid cardiovascular risk factors in the Gypsyny minority of Western Slovakia. Cor Vasa 2003; 45 (6): 333-336.

46. Fedačko J, Pella D, Jarčuška P. et al. Prevalence of cardiovascular risk factors in relation to metabolic syndrome in the Gypsy population compared with the non-Gypsy population in the eastern part of Slovakia. Centr Eur J Public Health, Supplement 2014; 22: S69-S74.

47. Nozdrovický P. Úmrtnost' Rómov na kardiovaskulárne ochorenia. Slov Lekar 1991; 2: 13-14.

48. Babinská I, Madarasová Gecková A, Jarčuška $\mathbf{P}$ et al. Does the population living in Gypsy settlements differ in physical activity, smoking and alcohol consumption from the majority population in Slovakia? Centr Eur J Public Health, Supplement 2014; 22: S22-S27.

49. Belák A. Health-system limitations of Gypsy health in Slovakia. A qualitative study. Bratislava: WHO Country Office, 2013: 54.

50. Kumanová Z, Džambazovič $\mathbf{R}$. Rómska rodina: na rozhraní medzi tradicionalitou a modernitou. 503-526. In: Vašečka M (Ed). Čačipen pal o Gypsy. Súhrnná správa o Rómoch na Slovensku. Bratislava: IVO, 2002.

Received March 2, 2015. Accepted June 26, 2015. 